\title{
Living on the Edge
}

\author{
Adam O. Goldstein, MD, MPH
}

\begin{abstract}
This essay describes a remarkable patient with severe medical and psychological problems who died a tragic death when she was only 46 years old. Despite suffering early coronary artery disease, persistent abuse from her spouse, and caring for a daughter with severe physical handicaps, the patient did not complain or seek pity for her condition. Rather, through ber belief in God and a focus on the day forward rather than the day behind, she reminds clinicians that the sum of a person's life is more than their medical problems. After the patient's death, her husband's medical problems force him to seek care; this raised ethical issues because the doctor who was treating him also cared for his wife. (J Am Board Fam Med 2011;24:211-213.)
\end{abstract}

Keywords: Anxiety, Battered Women, Domestic Violence, Ethics and Humanities, Spirituality

Virginia died on December 1 after living much of life on the edge. She was only 46 years old, but her medical history and experiences made her look and feel much older. Virginia had an unfortunate combination of severe, premature coronary artery disease and severe, persistent spousal abuse. Her husband was also a long-term patient of a colleague, creating additional ethical issues for us as family physicians who want to care for the entire family. Though Virginia's life and death are tragic, they raise important points for clinicians to consider as they care for patients with severe medical and social problems. As clinicians, we learn many things from our patients, but we rarely acknowledge those lessons while our patients are alive, much less deceased. This essay reflects on the lessons that Virginia taught all of us over many years-reflections that allow her influence to stay alive in the teaching of new physicians and in the care of new patients.

Virginia's medical history included severe heart disease, unusual for a patient so young. She had her first heart bypass surgery at age 40; her major risk factors included a 25-year tobacco habit and an

This article was externally peer reviewed.

Submitted 29 July 2009; revised 19 July 2010; accepted 30 July 2010.

From the Department of Family Medicine, University of North Carolina School of Medicine, Chapel Hill.

Funding: none.

Conflict of interest: none declared.

Corresponding author: Adam O. Goldstein, MD, MPH, University of North Carolina School of Medicine, Chapel Hill, NC 27599 (E-mail: aog@med.unc.edu). elevated cholesterol level. She also possessed bad genes; her father died from metastatic lung cancer when she was 32, and during her father's funeral her aunt had 4-vessel bypass surgery. Virginia herself had coronary stents placed twice and, despite these problems, she could not quit smoking. Subsequently, she developed refractory daily angina. She taught myself and my colleagues, including residents and students, about chest pain and heart disease: that it does happen to young women, that smoking and smoking cessation matter, that you must know intimately all the options available to treat heart disease, that many patients desire to have their primary care physicians manage highly complex issues, and that differentiating chest pain from anxiety versus chest pain caused by angina is never easy for any doctor.

Virginia clearly had severe anxiety, which complicated her coronary heart disease, though it would be a mistake to attribute the source of the anxiety solely to such illness. Though, naturally, she worried that she would drop dead any day from a massive heart attack, she did not overtly dwell on that possibility. Neither did she seem to worry excessively about the need to take multiple expensive medications with severely constrained financial resources. Instead of complaining, she asked for and received valium and a selective serotonin reuptake inhibitor for the treatment of her daily panic attacks. She agreed to see a therapist and psychiatrist intermittently, but the complexities of managing these visits in the context of multiple other 
doctor visits, along with the costs of mental health care, always lead her back to us for the treatment of her mental health needs. Trying to provide coordinated and comprehensive care to Virginia was not easy, and she taught us that the separation of mental health from primary care is inadequate at best and potentially dangerous. She would have approved of the bourgeoning efforts to integrate primary care and mental health. She died too soon to appreciate or receive benefit from the promise of the primary care medical home, a medical home with an interdisciplinary group of providers that patients such as Virginia optimally need.

This lack of obsession about her own difficulties is what made Virginia's life and death quite striking. Rather, she had a passion for living, a passion that seemed to emanate both from her faith and her experience. After college, she had hoped to enter divinity school, intent on becoming a counselor. She clearly acquired multiple pastoral skills despite not receiving such a degree. She possessed a deeprooted faith in God and spiritual issues that manifested as a belief that God had a purpose for her on earth and that she would die when God was ready for her to die. She felt that her physicians derived their healing power from God.

Virginia also loved to write. She wrote essays offering theological insights into the nature of suffering, evil, and good. She wrote frequent letters to her young daughter, writings which she hoped her daughter would read again as an adult, long past the time Virginia believed she would be alive. She described her daughter as the "umbilical cord of her existence." When she told me one day that her young daughter, then 2 years old, had a congenital muscle problem and would become brace-bound for walking, I became quite overwhelmed by the extent of her continued suffering. Yet Virginia shared this information not to seek pity but to let me know that her daughter was unique and that she would develop profound compassion and insights into other people's pain as a result of her own experiences. In the face of difficulties that would tackle most, Virginia had little time for or interest in pity. Rather, she seemed to possess a determination not to worry about tomorrow but to live each day for itself, as Matthew preached in the New Testament.

Virginia's medical and mental health conditions clearly included adverse outcomes associated with spousal abuse at the hands of an alcoholic husband.
She described the emotional, verbal, and physical abuse that occurred mostly when her husband drank alcohol, usually in binges. Calling her "worthless" and "ugly," he could strike as quickly with words as with his fists. She would often sleep in her living room, afraid to go into her bedroom. One night she developed an intractable nerve palsy in her foot after falling asleep awkwardly on the sofa. Despite a restraining order and an active case file with social services, her husband constantly asked her to get back together. Against medical advice and to the bewilderment of many of her providers, she often agreed, talking about compassion and her husband's mental illness.

One day near the end, Virginia told me that her husband had threatened their daughter, and she swore once again that she would never go back. She pressed for charges with law and social services, but the lack of proof or actual violence limited their options. She knew, however, that if she died, her husband would attempt to gain custody of their daughter; while Virginia was alive, her husband constantly told her that she was incapable of performing essential parental duties.

Clinicians today know a great deal more about domestic violence than they did a generation ago. They know that millions of women are abused every year by spouses or boyfriends, that more than one-third are subject to verbal and emotional abuse, that almost one third of women going to the emergency room have injuries caused by battering, and that more than 1100 women are killed annually by an intimate partner. Virginia taught us that these statistics only tell part of the story-many women return to their abuser time and again, and, despite our urgings or interventions, the abuse rarely ends. Virginia also taught us that our model of family medicine of caring for the family faces limits when clinicians who care for the victim also care for the perpetrator. Virginia's husband received his care through my colleague in a nearby practice, and we communicated about the common medical, psychological, and ethical issues we faced when caring for this "family."

One evening in late summer, as I was attending at our hospital inpatient service, the residents told me about a patient who needed to be admitted because of chest pain. The patient also had a history of alcohol abuse and was voicing suicidal ideations because of the recent death of his wife. I went to see the patient, and, after talking with him 
for a few minutes and listening to him talk about his wife, I suddenly realized that this drunken patient was Virginia's alcoholic and abusive husband. $\mathrm{He}$ told me that that Virginia had died one month before of a massive heart attack. Her young daughter, now 5, had apparently found her dead on the living room floor and called the police.

Sometimes the starkness of finding out about our patients' deaths hits us with such force that we become emotionally paralyzed. Such paralysis gripped me as Virginia's entire life as I knew ither medical encounters, stories, trials, and tribulations-flooded my active thoughts. As Virginia's husband continued to talk, I realized that I was so distracted that I could not provide optimal or objective care to him that evening. Instead, I called another colleague and asked him to finish the admission.

That night, I dreamed about Virginia, imagining how she died and what it was like for her daughter to find her in their home. I also I wondered if I could or should care for Virginia's husband the next morning. I found little to no guidance about these issues in the medical literature. I decided that I could give excellent care to him, despite the natural feelings of disgust and horror that arose. I think Virginia would have wanted me to provide such care, too. Her ability to forgive was at the root of her compassion.
On morning rounds, I decided to see her husband after fully informing the team of the involved issues. We went in to ask how he was doing, and as I introduced myself again as the attending physician, right away he said, "Yeah, you were the doctor that cared for Virginia." I suspected that he had also dreamed about her that night. He continued, "You know, I bet she said bad things about me to you. They weren't true. She always asked me to come back, and I never hurt the girl. I know I drink too much, but I loved her."

Sitting there quietly, I listened and let him talk without saying a word. After he finished, I gave him the option of having another physician provide his hospital care, but he declined, saying that he knew that because I had been her doctor I would give him good care. During the next 2 days, we ruled out a heart attack, made sure he was safe, and arranged referrals to appropriate community agencies. I decided not to talk with him about Virginia, and her family took custody of their daughter.

Virginia died because of heart disease and spousal abuse. Thinking of the abuse makes me angry, but I know that Virginia had little time for anger in her own life. Rather, she thought about the future, the one element she could mold or shape today for the better. In her final lesson, she taught me to let go of my anger, pray for healing and for all those that are living, and ultimately to see hope where others see despair. 